\title{
Lessons from a costs analysis in potato production
}

\author{
Gilson Rogério Marcomini ${ }^{1 *}$, Marco Tulio Ospina Patino², Mohammad Jahangir Alam³, \\ Fernando Rodrigues de Amorim ${ }^{4}$
}

${ }^{1}$ Professor, Federal Institute of Education Science and Technology of São Paulo (IFSP), São João da Boa Vista Campus. Lauro Sargaco Street. Jardim Santa Helena. CEP 13874057. São João da Boa Vista, SP. Brazil, ${ }^{2}$ Professor, State University of Campinas. Faculty of Agricultural Engineering. Av. Cândido Rondon, 501. CEP 13083-875. Cidade Universitária, Campinas, SP. Brazil, ${ }^{3}$ Professor, Department of Agribusiness and Marketing. Faculty of Agricultural Economics and Rural Sociology. Bangladesh Agricultural University, Mymensingh-2202, Bangladesh, ${ }^{4}$ Ph.D. student, State University of Campinas. Faculty of Agricultural Engineering. Av. Cândido Rondon, 501. CEP 13083-875. Cidade Universitária, Campinas, SP. Brazil

\section{A B S TR A C T}

\begin{abstract}
The potato is one of the most widely cultivated horticultural crops in the world. Brazil ranks $21^{\text {st }}$ among the world's largest potato producers, and the United States (US) is the fifth largest producer in the world. This study analyzes and compares the economic, financial aspects of potato production in the Vargem Grande do Sul region, SP (Brazil), and southwestern Idaho (US), seeking to identify which aspects of American production can serve as reference for technical and financial improvement of the Brazilian production. Data from official sources were analyzed using principal components analysis (PCA). Potato producer in Vargem Grande do Sul need learning how to reduce the factors of production costs to have better financial results in your potato production.
\end{abstract}

Keywords: Agribusiness; Agricultural production; Financial; Food systems; Production factors

\section{INTRODUCTION}

As the fourth largest crop by global production volume, the potato is one of the most cultivated horticultural crops worldwide. World potato production in 2016 was over 377 million tons, harvested from almost 19 million hectares, an average yield of around 20 tons per hectare (FAOSTAT, 2018). This global potato production was only smaller than whey (750 million tons in 2016), rice (740 million tons in 2016), and maize (1.06 billion tons in 2016) (FAOSTAT, 2018). It is a crop that is widely consumed worldwide, due to its ease of preparation, characteristics, and the innumerable possible ways in which potatoes can be consumed. Whether traditionally cooked, fried, or roasted, or as a component of other recipes, it is a product that all people can afford.

The largest Brazilian producer state is Minas Gerais, with production of 1.26 million tons in 2016 in an area of 39,431 hectares; this represents about 33 percent of the national (Brazilian) production. The second largest Brazilian producer state is Parana, producing 775 thousand tons in an area of 30,249 hectares, with Sao Paulo in third place, producing
665 thousand tons in 21,651 hectares. These three states together produce 75 percent of Brazil's total production, which corresponds to about 2.7 million tons (IBGE, 2018).

On the other hand, potato production in the US is higher than that in Brazil, and it ranks as the fifth largest producer in the world. The potato is produced in the US in three harvests throughout the year: in the autumn, spring, and summer. The fall harvest is the most important; about 376 thousand hectares are cultivated and produce about 18 million tons of potatoes (USDA, 2018). The main producing states in the US are Idaho, Washington, Wisconsin, North Dakota, and Colorado, which together account for 84 percent of the country's total potato production (USDA, 2018). The US potato market has the same characteristics as the Brazilian market, since prices fluctuate depending on the crop and the period.

The potato production costs indicate that the average total costs in southwestern Idaho in 2010 was US\$ 6,503.79 per hectare, while in 2017 the average total costs reached US\$ 8,573.86 per hectare. Likewise, the total production

\footnotetext{
${ }^{*}$ Corresponding author:
}

Gilson Rogerio Marcomini, Professor, Federal Institute of Education Science and Technology of São Paulo (IFSP), São João da Boa Vista Campus, Lauro Sargaco Street, Jardim Santa Helena. CEP 13874057. São João da Boa Vista, SP. Brazil. E-mail: gilson.professor@yahoo.com.br 
costs in the Vargem Grande do Sul region in 2010 were US $\$ 11,581.59$ per hectare, reaching US $\$ 13,209.44$ per hectare in 2012, US $\$ 9,314.04$ in 2015, and US $\$ 10,831.22$ in 2017.

Analyzing the structure of costs in the two areas shows that in southwestern Idaho, the highest costs are related to land leasing, fertilizers, pesticides, seeds, and machinery. Likewise, for the Vargem Grande do Sul region, the highest cost items are seeds, post-harvest and sorting, fertilizer, labor, and pesticides.

Thus, it is possible to deduce that potato production in the US has advantages over Brazilian production, allowing it to serve as a benchmark for Brazilian producers, with the goal of obtaining better results and becoming more competitive.

Faced with this, a comparative economic analysis of potato production in Brazil (Vargem Grande do Sul region), and in the United States (the southwestern region of Idaho) was performed, which allows for better understanding of the production costs, prices received by producers, and gross and net operating revenue in each region, as well as investigation of each region's cost structure, allowing identification of the operational and financial advantages of each region.

In this context, this study's main objective is to analyze and compare the economic, financial aspects of potato production in the Vargem Grande do Sul region, SP (Brazil), and southwestern Idaho (US), seeking to identify which aspects of American production can serve as reference for technical and financial improvement of the Brazilian production.

\section{MATERIALS AND METHODS}

Data from official sources was used to describe the economic aspects of potato production in the regions in Brazil and the US. The analysis was restricted to southwestern Idaho, the largest potato producer in the United States, which is subdivided into three potato producing regions and the region of Vargem Grande do Sul, in the state of São Paulo, Brazil, which accounts for 60 percent of Brazilian winter potato production and approximately 20 percent of Brazil's total production.

This information was used to conduct comparative economic and financial analyses of the two regions, taking into account the values of gross revenues, total costs, and profit. To verify the relationships, principal components analysis (PCA) was used for each of the two regions, considering the same eleven cost component variables (seed, fertilizer, pesticides, irrigation, machinery, labor, post-harvesting and sorting, fees and assessment, tractor depreciation, land leasing, and overhead) for the period between 2009 and 2017.

Principal component analysis (PCA) is a statistical tool that is used to reduce data sets that are large and complex, whereby this reduction is made by transforming the data into new variables (principal components). These new variables house most of the dataset, becoming a few components, which facilitate the analysis and interpretation of the original data (Todorov, H., Fournier, D., Gerber, S., 2018)

\section{RESULTS AND DISCUSSION}

The analysis of production costs demonstrates which region has an advantage in the individual cost components to obtain benchmarks for the other region. It is expected that certain cost structure aspects of potato production in the US will be more advantageous, serving as suggestions for production in the state of São Paulo. Fig. 1 shows that there is great fluctuation in the prices received by producers in the Vargem Grande do Sul region (SP), mainly due to the region's level of potato production. In some years, such as 2009, 2012, and 2015 , the volume produced was very high, which resulted in low prices. On the other hand, production was low in 2010, 2011, 2013, and 2017 and prices were higher.

Analyzing these variations in the volume produced and the prices received by producers, in 2010, compared to 2009 , there was a decrease of 12 percent in potato production in the Vargem Grande do Sul region and an increase of 403 percent in the prices received by producers. Similarly, there was an 11 percent decrease in production in 2011 and an increase of 188 percent in prices, while in 2017, production decreased by 30 percent and prices increased by 41 percent.

The results show there was less price instability in the United States than in Brazil. In 2009, the average price received by US producers was $\$ 165.34$, which fell to $\$ 154.32$ in 2010 , returned to $\$ 165.34$ in 2011, fell again in 2014 to $\$ 159.83$, and closed in 2017 at $\$ 170.86$. In 2010, therefore, production decreased by 15 percent and prices fell by 7 percent, while production fell by 8 percent in 2011 with no change in prices, and by 2017, there was a 6 percent reduction in production and a 7 percent increase in prices.

The average production yield in the southwestern region of Idaho in 2009 and 2017 was 59.38 and 56 tons per hectare, respectively, while it was only 28.12 and 30.78 tons per hectare in Vargem Grande do Sul, showing that the US state achieved a higher yield than the Brazilian state. It also indicates that the yield in the two regions remained stable 
in the period between 2009 and 201; however, the most striking fact is the yield difference between the two regions. The average yield in the southwestern Idaho region was 57 tons per hectare, while it was only 28 tons per hectare in the Brazilian region. This higher yield in the southwestern region of Idaho can be explained by edaphoclimatic factors, seed technology, and increased fertilizer use.

Using the yield information and prices received by producers, it is possible to compute the average gross operating revenue obtained each year in each region, which is shown in Fig. 2. The average gross operating revenues in the southwestern region of Idaho are stable, with values each year close to around US \$9,500 per hectare. In the Vargem Grande do Sul region, however, the fluctuations each year are larger; in some years, average gross operating revenues per hectare have been US \$5,041 (2014), while in others, they have reached US $\$ 15,175$ (2016) per hectare.

The profitability of potato production in the two regions can be estimated by calculating the gross operating profit, obtained as the difference between gross operating revenues and total production costs. Disregarding inflationary adjustments, the potato producers in southwestern Idaho experienced negative results in 2011 and 2012; in all other years, the results were positive, resulting in total financial gains of US\$4,720.85 per hectare between 2009 and 2017. In the Vargem Grande do Sul region, negative results were found in 2010, 2011, 2012, 2014, and 2017, and in the other years $(2009,2013,2015$, and 2016) the results were positive, giving rise to a negative value of US\$18,116.95 per hectare for the entire period.

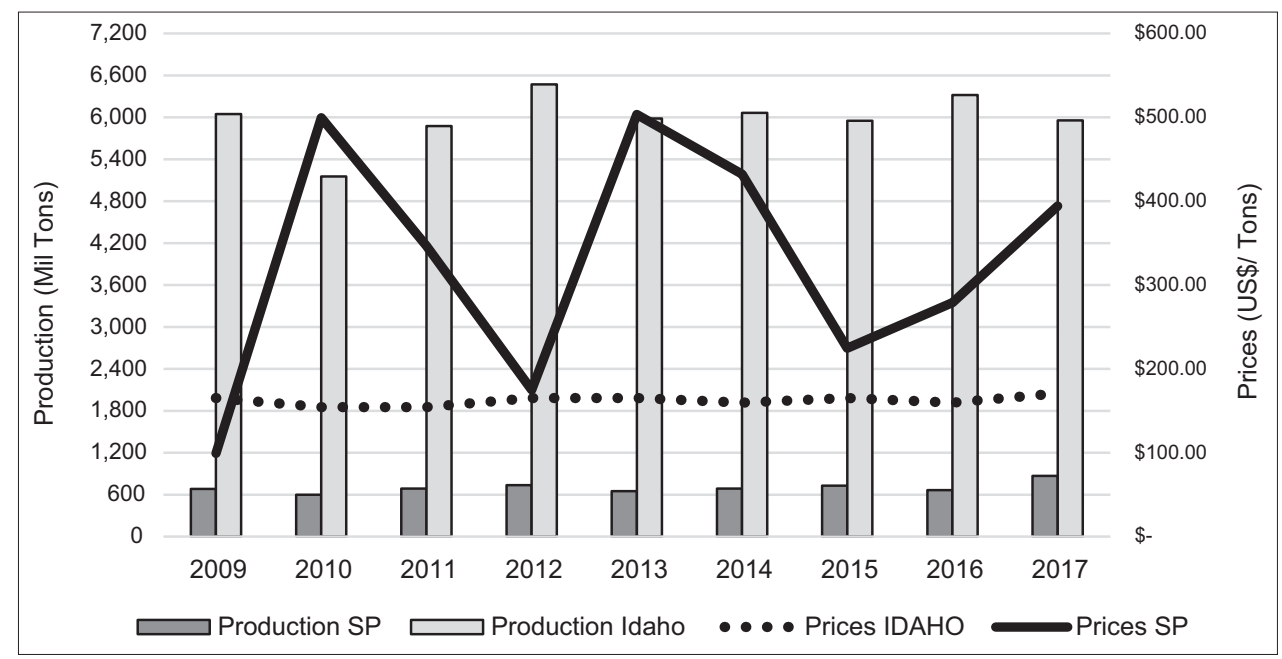

Fig 1. Production and prices. Source: Authors calculation based on data from IBGE (2018); HortifrutiBrasil/CEPEA-Esalq-USP (2018); Patterson (2014); Patterson (2015); Patterson (2016); Eborn (2017); USDA (2018).

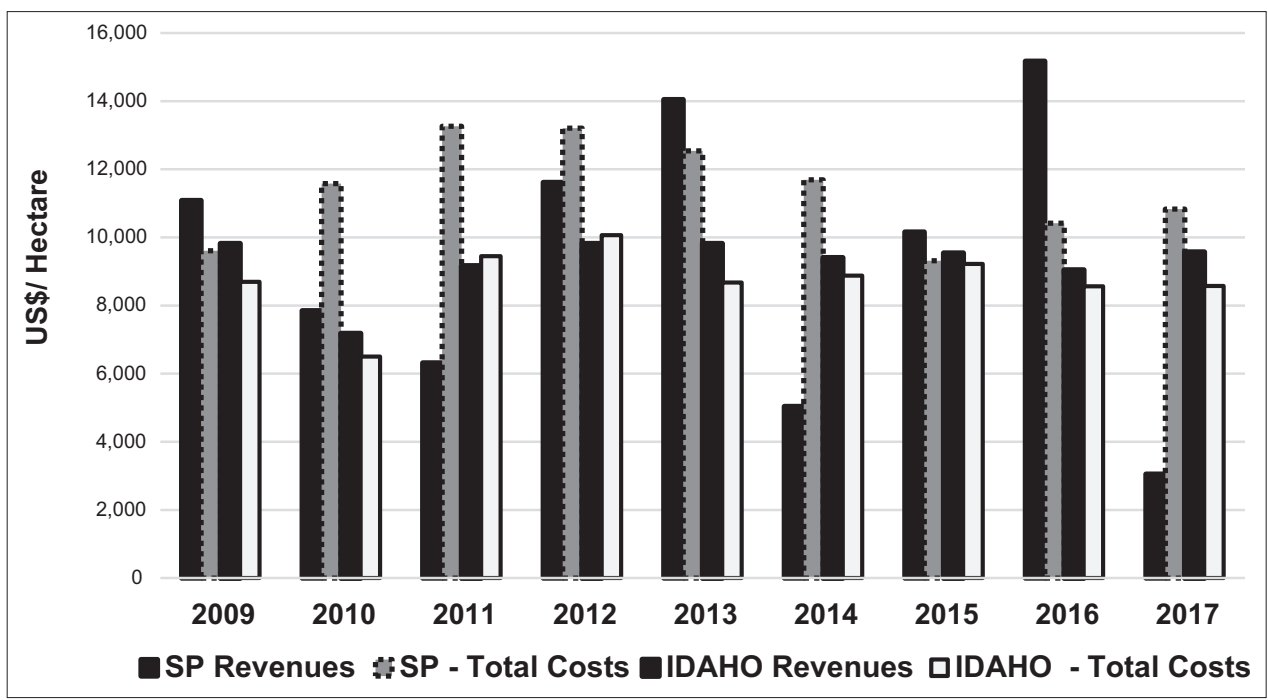

Fig 2. Revenue and total costs. Source: Authors calculation based on data from Patterson (2014); Patterson (2015); Patterson (2016); Eborn (2017); USDA (2018); HortifrutiBrasil/CEPEA-Esalq-USP(2018); IBGE (2018). 
Comparing the two regions, it can be seen that the prices paid to producers in southwestern Idaho are lower than those in the Vargem Grande do Sul region, but the average production yield is higher, and the costs of production are lower, producing better financial results for southwestern Idaho. Table 1 shows that in southwestern Idaho, the highest costs are related to land leasing, fertilizers, pesticides, seeds, and machinery, and for the Vargem Grande do Sul region, the highest cost items are seeds, post-harvest and sorting, fertilizer, labor, and pesticides.

An examination of the seed costs of the two regions (Fig. 3) reveals that in southwestern Idaho, the average annual costs were around US $\$ 893.00$ per hectare, while in the Vargem Grande do Sul region, the annual average was US $\$ 2,082$ per hectare. This cost component is extremely complex in the Brazilian region, due to the multiplication processes that are necessary for Brazilian plantations. Unlike in southwestern Idaho, where seeds are produced in the region and have less impact on the total cost of potato

Table 1. Cost Components Analysis

\begin{tabular}{llc}
\hline Cost Component (US\$ Hectare) & Region & $\mathbf{2 0 1 7}$ \\
\hline Seed & Southwestern of Idaho & 928 \\
& São Paulo & 1.563 \\
Fertilizer & Southwestern of Idaho & 1.002 \\
& São Paulo & 1.306 \\
Chemicls/Pesticides & Southwestern of Idaho & 1.421 \\
& São Paulo & 850 \\
Machinery & Southwestern of Idaho & 712 \\
& São Paulo & 507 \\
Labor & Southwestern of Idaho & 586 \\
& São Paulo & 1.408 \\
Post-Harvest and Sorting & Southwestern of Idaho & 185 \\
& São Paulo & 2.695 \\
Land & Southwestern of Idaho & 1.729 \\
& São Paulo & 775 \\
\hline
\end{tabular}

Source: Authors calculations based on Patterson (2014); Patterson (2015); Patterson (2016); Eborn (2017); HortifrutiBrasil/CEPEA-Esalq-USP (2018) production, the parent seeds for Brazil are imported from European countries and then multiplied in the region.

Similarly, when analyzing fertilizer costs in the two regions, the annual costs in southwestern Idaho average US $\$ 1,241$ per hectare, and those in the Vargem Grande do Sul region average US $\$ 1,491$ per hectare, approximately 20 percent higher in the latter than in the former.

Likewise, the average annual labor costs in southwestern Idaho are around US $\$ 555$ per hectare, whereas the total annual labor cost in the Vargem Grande do Sul region averages US $\$ 1,311$ per hectare, almost 237 percent higher than in southwestern Idaho. This higher cost in the Vargem Grande do Sul region can be explained by the intense use of labor in harvesting operations, since almost all properties employ a semi-mechanized harvesting system. A possible solution for reducing this cost would be to completely mechanize the harvest operations, as is done in southwestern Idaho (Fig. 4).

We also analyze the costs of post-harvesting and sorting in the two regions; the results show that in southwestern Idaho, post-harvesting and sorting generate an average annual cost of around US $\$ 188$ per hectare. On the other hand, in the Vargem Grande do Sul region, the average annual cost is US $\$ 2,036$ per hectare-1,082 percent higher than in southwestern Idaho. The high cost in this region of Brazil can explained by the fact that almost all potatoes harvested in the region undergo a washing and classification process, which is required by the Brazilian market. The most aggravating fact in this context is that almost all potato producers in the region outsource this operation, which increases the cost.

Another constraint in the Vargem Grande do Sul region is the fact that marketing is carried out through middlemen agents, who link producers with wholesalers and retailers.

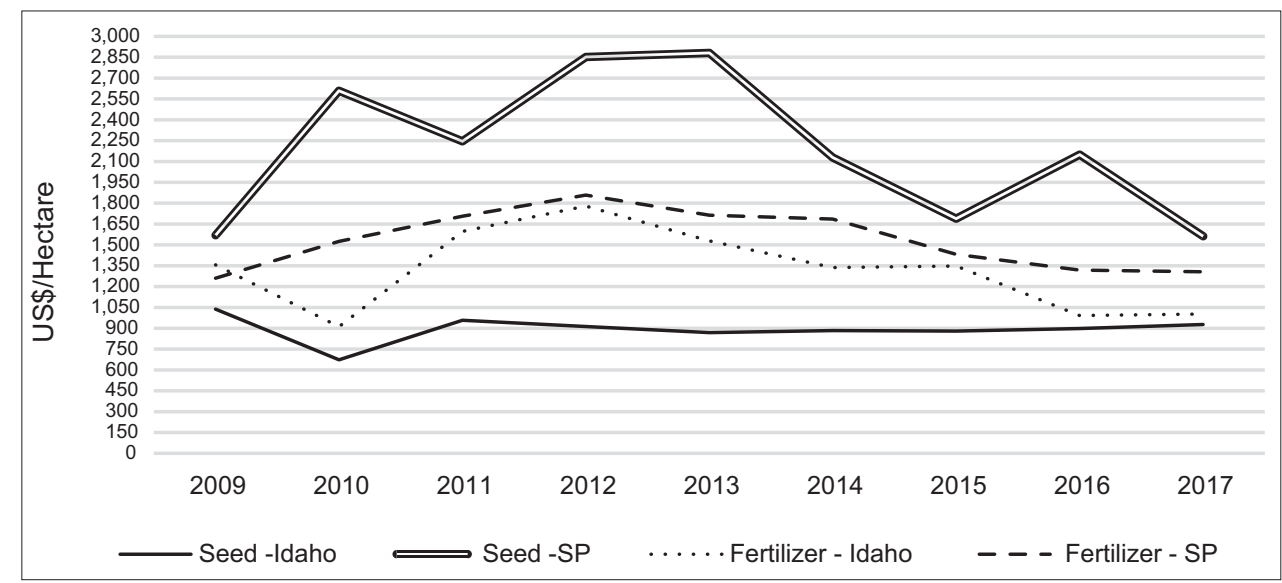

Fig 3. Seeds and fertilizer'costs. Source: Authors calculation based on data from Patterson (2014); Patterson (2015); Patterson (2016); Eborn (2017); Revista HortifrutiBrasil/CEPEA-Esalq-USP (2018). 


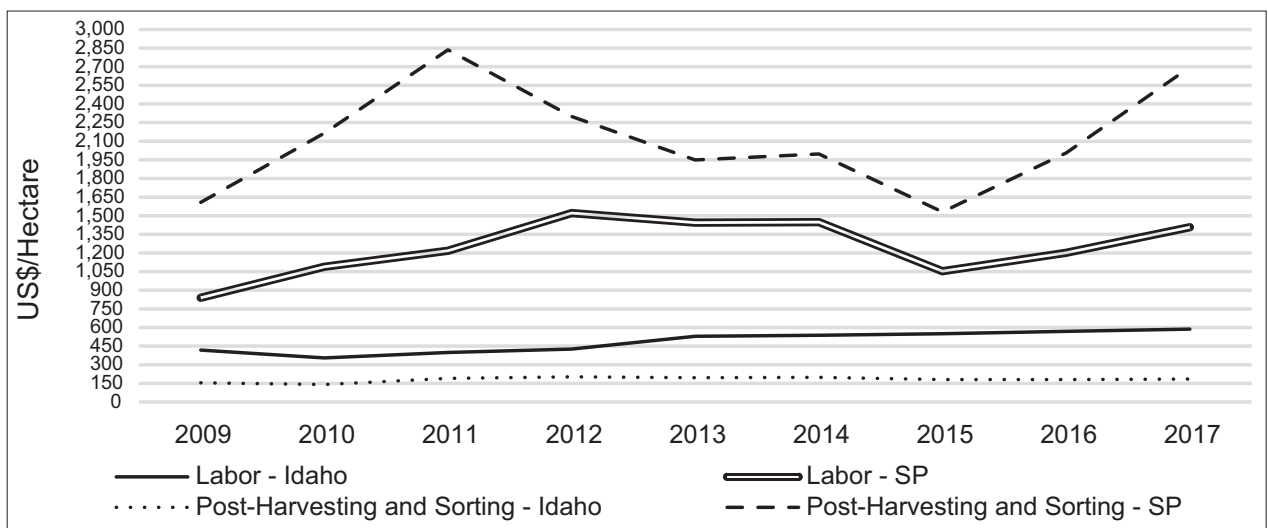

Fig 4. Labor and post harvest/sorting'costs. Source: Authors calculation based on data from Patterson (2014); Patterson (2015); Patterson (2016); Eborn (2017); Revista HortifrutiBrasil/CEPEA-Esalq-USP(2018).

These agents are very important for marketing the potatoes produced in the region because they maintain contact with major wholesalers and retailers and deliver the entire production to consumer markets. However, the agents charge costs that reduce the viability of the business for producers, particularly in years when prices are low.

The costs of pesticides and machinery are larger in southwestern Idaho than in the Vargem Grande do Sul region but have less impact on total costs. In the case of pesticides, the average values are similar in both regions: US $\$ 1,446$ per hectare in southwestern Idaho and US $\$ 1,090$ in the Vargem Grande do Sul region. Likewise, machinery costs are higher in southwestern Idaho (US $\$ 740$ per hectare), due to the greater use of mechanization in that region, mainly because of mechanized harvesting, while in the Vargem Grande do Sul region, the harvest activities are done manually (US $\$ 484$ per hectare).

In developing the relationships between the two main components for producers in the Vargem Grande do Sul region, principal components analysis showed that the first four major components $(\mathrm{CP})$ have eigenvalues greater than one and explain about 89 percent of the total variation, while each contributes about $40,26,14$, and 9 percent, respectively. The first major component (F1) is strongly correlated with 4 of the 11 variables, showing correlation values above 0.3 , including correlation with the variable "fertilizers" of 0.4 , as shown in Fig. 5.

F1 is also correlated with the variables related to total costs of production, such as fertilizers, land leasing, sorting, seeds, labor, and pesticides. The second main component (F2) presents a higher correlation with irrigation variables, administrative costs, equipment depreciation, and, negatively, the overhead variable.

The principal components analysis for southwestern Idaho (US) showed that the first four main components (CP)

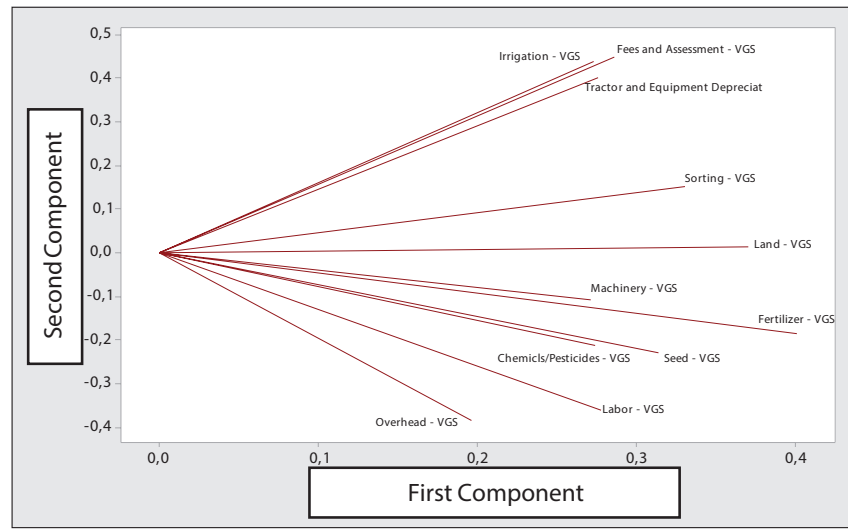

Fig 5. Relationship between the two main components for producers in Vargem Grande do Sul (SP). Source: The authors using data from HortifrutiBrasil/CEPEA-Esalq-USP (2018).

have eigenvalues greater than one (1) and explain about 98 percent of the total variation, while each one contributes about 50, 29, 14, and 5 percent, respectively. The first major component (F1) is strongly correlated with 2 of the 11 variables, with correlation values above 0.4 . F1 is more correlated with variables related to pesticides, overhead, and land leasing, and this association between the variables F1 and F2 is highlighted in Fig. 6. The second main component (F2) shows a stronger correlation with variable machinery.

Thus, the cost components that most impact potato production in the Vargem Grande do Sul region are fertilizers, seeds, land, labor, and sorting, corroborating that the profitability gaps in production are strongly related to agricultural production factors. In contrast, in southwestern Idaho, the cost components most closely related to the profitability of potato production are pesticides, land, overhead, and mechanization.

Given this context, what lessons can Brazilian producers extract from potato production in Southwestern Idaho? With respect to reducing the costs of production factors, in potato production in the Vargem Grande do Sul, fertilizer 


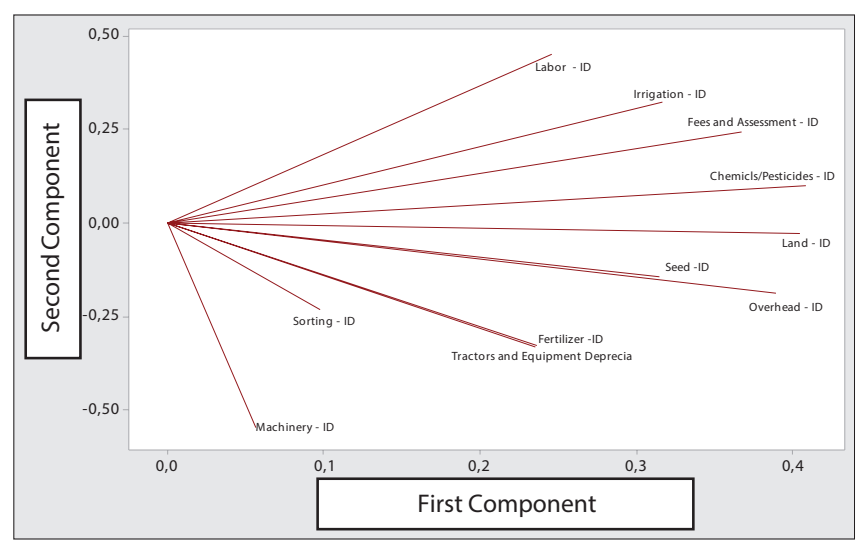

Fig 6. Relationship between the two main components for producers in Southwestern of Idaho. Source: Data used from Patterson (2014); Patterson (2015); Patterson (2016); Eborn (2017).

use accounts for 13 percent of average total costs, while other production factors that also impact production costs are seeds (19 percent), defensive (10 percent), work (12 percent), processing (19 percent), and land leasing (8 percent).

Carvalho et al., (2010) show that the high cost of seeds is due to their importation and the cold chamber storage system. Some potential actions would reduce these costs, such as new growing technologies, seed multiplication and storage, and reducing the region's dependence on imports, including the use of varieties developed in country. Although this is not an easy task, there is research that addresses this scope and can, in the short and medium term, reduce dependence on imported seeds.

The adoption of modern and technological pesticide products with smaller applications per area and increased efficiency, which are already available in the market, becomes essential for cost reduction. In addition, if the culture is healthy, with good nutritional levels, pest and disease attacks will be diminished. Producers need to be attentive to new technologies, since the reduction process must be constant. Purchases of pesticides by producer associations and cooperatives are also approaches that can reduce costs, since purchasing greater quantities increases trading power. In the context of pest and disease control, the adoption of biological control can also help reduce production costs.

The labor factor is perhaps one of the most important aspects in this analysis, since it accounts for 12 percent of total costs. Looking at the lessons of production in southwestern Idaho, we found that the solution would be the complete mechanization of the crop. This is already done in some regions of Brazil by large producers, but the number of producers who implement such a process is small. It is necessary to analyze the investment required, which is still high, but studies show that this investment is financially viable, mainly due to the reduced amount of labor compared to the semi-mechanized system. Land leasing is a common practice, as it becomes more advantageous for producers to absorb the cost of renting land rather than to invest in land acquisition. One solution would be negotiating with landowners to reduce the amounts paid, or planting other crops in the same area, such as corn, soybeans, and beans, as part of a system of crop diversification and rotation.

In addition to mechanizing the harvest, the post-harvest processing, which is mostly carried out by third parties, is responsible for 19 percent of total production costs. Similarly, the beneficiation process requires large investments when performed by the farm itself and can be made more financially viable by substituting outsourcing. A palliative measure would be the joint realization of the investments necessary for mechanizing the harvest and beneficiation through an association of producers, cooperatives, or producer pool for this purpose, including being able to provide services to other producers, generating extraordinary revenues. The potato marketing process is totally disadvantageous for producers, especially in low-price years, since practically all producers in the region use market agents (brokers) to sell their potatoes. These agents are the link between the rural producers and the wholesale and retail sectors and perform the planning and scheduling tasks for product delivery. Brokers receive the wholesaler and retailer demands and pass these to the producers, organizing the product's delivery process. In the same way, it is the agent who makes payments to the producers and determines other marketing actions.

Thus, the agent ends up having great power in the market (Carvalho et al., 2010), providing an essential link for rural producers to commercialize their production. Moreover, this link provides an important contact between the wholesalers and retailers to producers in several Brazilian regions to supply potatoes throughout the year, meeting the demands of these sectors downstream of production. However, rural producers do not have any form of guarantee of financial receipts or prices and assume all market risks, due to the absence of formal marketing contracts and the informality of the process. This corroborates Carvalho et al., (2010) study. It is common for producers to face default by brokers or receive insignificant prices, well below the break-even values. One possible solution would be for producers to organize and seek new forms of marketing, perhaps by working directly with wholesalers and retailers. They could also opt for investments in production storage, using new technologies that exist in European countries, which provide good operating results and maintain product quality for longer periods of time at low cost per unit of 
production. Still in the scope of commercialization, another solution would be to diversify the forms of sale, dividing the production between the market in nature and the chips and frozen potato chips industries.

Finally, prices are a more complex aspect, as they depend on variables such as production, time of year, market power, etc. However, producers have some opportunities to increase prices, such as attempting to have their product on the market when there is less supply, that is, to plan the crop cycle so that harvest occurs before or after the region's peak production. Since peak production occurs between May and October, producers should try to schedule their harvest before May or after October, especially in low-price years. Another possibility would be to store the production for later commercialization by making investments in storage, notably in cold rooms. These are commonly used in European countries for this purpose, but are more prominently used in Brazil for seed storage. Likewise, production cycles could be planned based on historical production and price series; when two or three years of low prices are observed, producers could reduce the area to be planted, minimizing negative results, and increase planting areas in years of higher price trends.

\section{CONCLUSIONS}

Lessons learned from potato production in southwestern Idaho expose the need for reduced costs of production factors, (such as seeds, fertilizer, labor and processing/ commercialization), whereas average total seed costs in the Vargem Grande do Sul region are 134\% higher than in the Southwestern Idaho region and the total average costs of fertilizers and processing/commercialization are $22 \%$ and 983\% higher than Southwestern Idaho, respectively. Labor factor is 137\% higher in Vargem Grande do Sul than Southwestern Idaho, but the machinery costs in Southwestern Idaho are 35\% higher than Vargem Grande do Sul, exposing the greater use of mechanization in potato production in Idaho. Potato producer in Vargem Grande do Sul need learning how to reduce the costs these components to have better financial results in your potato production, and there is the need for new research in these topics for helping them to improve these actions.

\section{ACKNOWLEDGMENTS}

The authors thank the Federal Institute of Education Science and Technology of São Paulo (IFSP), Coordination for the Improvement of Higher Education Personnel - Brazil (CAPES), State University of Campinas by Faculty of Agricultural Engineering for Financial assistance in this research, and to Editage for English language editing.

\section{Authors' contribution}

In this research, all authors contributed effectively. Gilson and Marco Túlio make an analysis of costs structure, analyzing fertilizer costs, the average annual labor costs, the costs of post-harvesting and sorting, the costs of pesticides and machinery in the two regions, how too diagnosed the profitability of potato production in the two regions. Fernando analyzing the volume produced and the prices received by producers, and was make the principal components analysis (PCA). Mohammad expose the lessons learned from potato production in Southwestern Idaho and revised the paper.

\section{REFERENCES}

Carvalho, N., D. Martinhago, C. Rocha and L. Q. de Melo. 2010. Efeitos da Assimetria de Informação Sobre os Custos de Transação da Cadeia Produtiva da Batata. VII Simposio de Excelência em Gestão e Tecnologia, p. 1-15.

Eborn, B. 2017. Potato Cost of Production for Southwestern of Idaho 2017 with Comparisons to 2016. Report to the Cost of Potato Production Advisory Committee, and the Southwestern of Idaho Potato Commission R and E Committee. Available from: http:// www.usouthwestern of idaho.edu/cals/southwestern of idahoagbiz. [Last accessed on 2019 Jan 23].

Food and Agricultural Organization of the United Nations Statistics Division (FAOSTAT). 2018. Available from: http://www.faostat3. fao.org/home/e. [Last accessed on 2019 Jan 20].

Instituto Brasileiro de Geografia e Estatística (IBGE). 2018. Produção Agrícola Municipal. Banco de DADOS SIDRA. Tabela 1001. Available from: http://www.sidra.ibge.gov.br. [Last accessed on 2019 Jan 23].

Patterson, P. 2014. Cost of Potato Production for Southwestern of Idaho with Comparisons to 2013. Report to the Cost of Potato Production Advisory Committee, and the Southwestern of Idaho Potato Commission R and E Committee. Available from: http:// www.usouthwestern of idaho.edu/cals/southwestern of idahoagbiz. [Last accessed on 2019 Jan 03].

Patterson, P. 2015. Southwestern of Idaho Potato Cost of Production: 2003-2014 and Five-year Trend. Journal Agricultural Economics Extension. University of Southwestern of Idaho. Available from: http://www.usouthwestern of idaho.edu/cals/southwestern of idaho-agbiz. [Last accessed on 2019 Jan 23].

Patterson, P. 2016. 2015 Cost of Potato Production for Southwestern of Idaho with Comparisons to 2014. Report to the Cost of Potato Production Advisory Committee, and the Southwestern of Idaho Potato Commission R and E Committee. Available from: http:// www.usouthwestern of idaho.edu/cals/southwestern of idahoagbiz. [Last accessed on 2019 Jan 18].

Revista Hortifrutibrasil/Cepea-Esalq-USP. 2018. Edições de 2009 a 2017. Available from: http://www.hfbrasil.org.br/br. [Last accessed on 2019 Jan 10].

Todorov, H., D. Fournier and S. Gerber. 2018. Principal components analysis: Theory and application to gene expression data analysis. Genomics Comput. Biol. 4(2). Available from: https:// www.genomicscomputbiol.org/ojs3/GCB/article/view/41/204. [Last accessed on 2019 Nov 20].

United States Departament Agriculture (USDA). 2016. National Agricultural Statistics Service: Quick Stats. Available from: https:// www.quickstats.nass.usda.gov. [Last accessed on 2019 Jan 12]. 